\title{
Peculiarities of Multicultural Education Development in North America, Western Europe and Ukraine
}

Enviado: 26 de julio de 2020 / Aceptado: 29 de septiembre de 2020

Publicado: 30 de diciembre de 2020

LEILA SULTANOVA

Ivan Ziaziun Institute of Pedagogical Education and Adult Education of the National Academy of Pedagogical Sciences of Ukraine

leilasultanova22.07@gmail.com

LIDIIA KHOMYCH

Ivan Ziaziun Institute of Pedagogical Education and Adult Education of the National Academy of Pedagogical Sciences of Ukraine

ukrlida@ukr.net

MARÍA R. BELANDO-MONTORO

Departamento de Estudios Educativos, Universidad Complutense de Madrid, España

mbelando@ucm.es

DOI 10.24310/IJNE3.2.2020.10030

\section{ABSTRACT}

The purpose of the article was to analyze the process of the multicultural education development in countries that have experience in the successful implementation of its ideas and to identify relevant for Ukraine ideas of multicultural education, as in Ukraine the number of foreign students in universities, academies and institutes is constantly growing.

In order to solve the tasks we used general scientific (analysis, synthesis, comparison, systematization and generalization for studying the works of foreign and domestic scientists and the legislative support) as well as special scientific (prognostic analysis for

\section{RESUMEN}

Peculiaridades del desarrollo de la ducación multicultural en América del Norte, Europa occidental y Ucrania

El propósito del artículo es analizar el proceso de desarrollo de la educación multicultural en los países que tienen experiencia en su aplicación satisfactoria e identificar las ideas pertinentes para Ucrania en materia de educación multicultural, ya que en Ucrania el número de estudiantes extranjeros en las universidades, academias e institutos aumenta constantemente.

Para abordar el objetivo planteado se utilizaron métodos de investigación científica general (análisis, 
determination of the multicultural education prospects in Ukraine) research methods.

Underway the study, the fact of the need for the multicultural education and its links with the social, economic and political factors in the global labor market, as well as with the migratory flow that requires the integration of immigrants into society, was found out. However, each country's multicultural education has its own peculiarities in relation to the legislative environment and the implementation of an inclusive education perspective at the different educational levels.

Keywords: multicultural education, migration, Ukraine. síntesis, comparación, sistematización y generalización para el estudio de las obras de los científicos extranjeros y nacionales y el apoyo legislativo), así como métodos de investigación científica especial (análisis de pronóstico para la determinación de las perspectivas de educación multicultural en Ucrania).

En el estudio se constató la necesidad de la educación multicultural y sus vínculos con los factores sociales, económicos y políticos del mercado laboral mundial, así como con el flujo migratorio que requiere la integración de los inmigrantes en la sociedad. Sin embargo, la educación multicultural de cada país tiene sus propias peculiaridades con relación al ámbito legislativo y a la aplicación de una perspectiva de educación inclusiva en los diferentes niveles educativos.

Palabras Clave: educación multicultural, migración, Ucrania.

\section{INTRODUCTION}

Today the issue of interaction between representatives of different cultures is laying in the center of politicians', culturologists' and sociologists', as well as the pedagogical community's attention. Such kind of attention is due to the trend of modern society, which consists in expanding of the relationship and interdependence between countries, peoples and their cultures. Various spheres of public life in countries all over the world are affected by this process.

It is almost impossible to find communities that are not influenced by the cultures of other peoples today. Major manifestation of such influence is the rapid growth of cultural exchanges and direct contacts between government institutions, social groups, social movements and individuals from different countries and cultures. The interaction of cultures and peoples makes the issue of cultural identity and cultural differences especially relevant.

The challenges of modern society are reflected in the ideas and practices of multicultural education around the world. However, despite the significant progress the world community has made in this direction in recent decades, the problem still remains. A vivid example is the recent protests in the United States and Europe aimed at combating against the racial discrimination. Solving the problems of intercultural interaction requires methodical work, long 
efforts and a dialogue. It is clear that it is necessary to act systematically, through changes in the field of education, reforms in the political sphere, legislative innovations, etc.

The history of multicultural education, which is one of the main tools for multiculturalism policies implementation in different countries, is described further. Peculiarities of multicultural education in the USA and Canada are analyzed; models of citizens' integration by means of multicultural education in the countries of Western Europe are revealed (in the United Kingdom of Great Britain and Northern Ireland, in the Federative Republic of Germany and in the French Republic). The legislative provision of multicultural education in Ukraine is highlighted as well. These countries were chosen due to their attractiveness to emigrants, as economically and politically developed countries, where multicultural education is potentially needed. As a result of such analysis, the socio-cultural preconditions for the emergence of multicultural education were revealed.

The purpose of the article was to analyze the process of the multicultural education development in countries that have experience in the successful implementation of its ideas and to identify relevant for Ukraine ideas of multicultural education, as in Ukraine the number of foreign students in universities, academies and institutes is constantly growing.

Ukraine is not one of the most attractive countries for immigrants, due to socioeconomic instability and lack of membership in the European Union and other political and economic associations that have a well-established policy to migrants' support). Nonetheless, according to the information provided by the State Statistics Service of Ukraine, at the beginning of 2016th-2017th, 52019 foreign students studied at universities, academies and institutes. Most of the students are from Azerbaijan (8823 people), Turkmenistan (6288 people), India (5885 people), Nigeria (3034 people), Morocco (2854) and other countries. Most of the foreigners study in Kharkiv, Kyiv, Odesa and Dnipro. By the 2014th, almost one fifth of foreigners studied in higher education establishments of the Autonomous Republic of Crimea, Donetsk and Luhansk.

\section{FEATURES OF MULTICULTURAL EDUCATION IN THE UNITED STATES}

In many countries around the world multicultural education is the leading strategy for the development of a multicultural society. The US multicultural education has undergone complex socio-cultural transformations in society aimed at intercultural interaction with representatives of other cultures. 
James Banks in his work «Multicultural Education: Historical Development, Dimentions and Practice» (Banks, 1993) identifies the following phases of multicultural education development in the United States:

The first phase of multicultural education (ethnological) is characterized by the actions initiation at the institutional level and the practical introduction into the pedagogical practice of concepts, theories from among the ethnic studies of American historians.

The second phase (multiethnic education) arose from the understanding that the introduction of ethnic research into the content of education and curricula is not a sufficient condition for school reform, which, in its turn, is aimed at developing more democratic racial and ethnic relations. It was necessary to achieve structural and systematic changes in the practice of education that would increase the overall educational equality.

The next phase (improvement of curricula) - provided for changes in the curricula of schools, colleges and universities, which would cover the history and culture of not only ethnic but also other groups of society who considered themselves inferior (women, people with disabilities, etc.).

The last phase (theoretical substantiation) is characterized by the development of theoretical provisions of multicultural education, research and practical implementation of all components of multicultural education, taking into account racial, class, gender and other diversity.

In this periodization it is worth noting that the researcher singles out the first (ethnological) phase of the formation of multicultural education. This is due to the fact that the period of emergence of multicultural education in the scientific community is considered to be 1960 - 1970, while James Banks argues that multicultural education has deep historical roots associated with the African-American movement of the late XIX ${ }^{\text {th }}$ - early $\mathrm{XX}^{\text {th }}$ century (Banks and Ambrosio, 2016).

Grant (2008) in his report on topic «The Evolution of Multicultural Education in the United States: a Journey for Human Rights and Social Justice», announced at the conference «CoLearning in a Multicultural Society: Critical Reflections» (Turin, Italy, 2008), connects the periods of multicultural education development with the social movements in society.

The first period (1930-1940) is associated with the intercultural movement caused by the immigration wave to the United States, mainly from Western Europe. The US ideology for immigrants was meant to assimilate, in other words, to fully Americanize, based on the values 
of «freedom», «equality», and «justice». It was the time when an intercultural movement emerged in order to recognize the cultures of immigrants.

The second period $(1940$ - 1950) took place within the intercultural educational movement. This time was characterized by racial tensions in society, caused by the migration of rural people, most of whom were African Americans, to the cities. Studies of the intergroup conflicts causes have become relevant in the educational environment. Among them, the most famous is the work of Gordon Allport (1954) «The Nature of Prejudice».

The next period (mid-1950's - mid-1960's of the twentieth century) was marked by a civil rights movement aimed at overcoming the laws and traditions of racial distribution.

Grant calls the last period (1960's - 1970's) the «Movement of Ethnic Studies». The reason was that at that time textbooks, didactic illustrations, etc. were checked for the information about the cultures of different ethnic groups.

Moreover, it was the time when the United States was experiencing a period of profound social changes. African Americans and other ethnic groups began to oppose the assimilation process, which required the abandonment of their cultural identity and heritage. They began to insist on the representation of their own culture in the schools curricula, colleges and universities in order to ensure the harmonious involvement of children both in the culture of the majority and in their own cultural traditions. As a result, there was a need to review the cultural heritage of the United States to meet the educational needs of its society, which has long ceased to be monocultural and has been a union of many cultures.

In the process of analyzing the history of multicultural education and the stages of its formation, presented in the works of James Banks and Carl Grant, we can state that this process is mainly related to migration, and originated as one of the ways to combat against the racism. Over time, the point of multicultural education has transformed. The conclusion concerning that multicultural education should meet the needs of different groups of society was drawn. Educational programs began to be developed with taking into account the needs of not only different races, but also other groups of society. As a result of educational reforms, the professional training of teachers who are able to work in a multicultural society has become mandatory. Today, multicultural education in the United States has the status of educational policy of the country, approved at the legislative level. In addition to that, the theory and practice of multicultural education in the United States still continues to develop. 


\section{FEATURES OF MULTICULTURAL EDUCATION IN CANADA}

Canada is the first country that officially introduced a policy of multiculturalism and is one of the few countries to grant it with the constitutional status. Canada is also still considered to be the country with the most effective international migration policy. Canadian multiculturalism is also associated with historical contradictions between the English-speaking and French-speaking communities.

The formation of Canadian multiculturalism experience passed through several stages (Веретевская, 2012 a). The formation of a bicultural state was just the first stage. This need arose due to the political situation in Canada in 1534. Some lands of Canada appeared at the same time to be in the jurisdiction of France and Britain at the same time. In addition to economic and political problems, there was a cultural difference between Anglo-Canadians and Franco-Canadians. This situation required finding solutions at the state level. The idea of a melting pot, which was successful in the United States, could not be implemented in Canada.

The second stage is the path to multiculturalism. In 1960, with the coming to rule of the liberal government, an attempt to introduce multiculturalism as a state policy aimed at the integration of the federal state was made. It was assumed that bilingualism, or the policy of bilingualism, could contribute to achieving national harmony, eliminating sharp contradictions between the English-speaking and French-speaking communities. Multiculturalism, introduced in Canada, was not only a response to the difficulties of cultural or ethnic minorities in the country, but also a way for Canada to emerge as a mosaic rather than a melting pot (Wieviorka, M., 1998, p. 884). The events of that time were called the «Silent Revolution». During the «Silent Revolution» from the 1960's to the 1980's, Quebec became a prospering Canadian province, where French became the official language.

In contrast to Anna Veretevskaya, Oksana Slonovska in her research singles out one more stage - the third one, in which the policy of multiculturalism was perceived by all segments of society (Слоньовська, 2011, с. 14).

Unlike other multinational states, Canada has used the principle of political interpretation of national identity, known since the time of the French Revolution, to resolve a number of economic, social, and cultural conflicts between Anglo- Canadian and Franco-Canadian populations: «no nation has a place in a nation» (Куропятник, 2000, с. 56). If in Europe multiculturalism is seen as a kind of initiative to recognize diversity, in Canada it has paved the way for the nation to move towards self-awareness. It was this idea that the creation of 
a single national identity while preserving the cultural diversity of the country's population had become the basis of Canadian multiculturalism, the main provisions of which were proposed by a special commission in the course of many years of research. Instead of ethnic diversity as an important basis for the identity of the population, the concepts of language and culture were proposed. Thus, Canadian multiculturalism is not aimed at the division of the national community, but at its formation with the recognition of diversity (even if it is sometimes purely declarative) as a basis.

Of course, the proclamation of multiculturalism did not immediately resolve the longstanding bicultural conflict between the French-speaking and the English-speaking population of Canada, as well as the social problems of indigenous peoples and other national minorities. However, this way of building a nation is gradually gaining the success. The desire for integration, both on the part of the Canadian population and on the part of the state, is growing every year. According to a Gallup World Poll study in 2012, Canada showed one of the highest results in the world in terms of citizens' trust in each other and in the state, as well as in terms of overall well-being and happiness (Landes, 2013).

Today, Canada is one of the most developed countries with the highest percentage of people born abroad. In 2011, this share was over $20.9 \%$, which is higher than in the United States (13.0\%), Great Britain (11.7\%) and most countries of the Organization for Economic Cooperation and Development (OECD, Organisation for Economic Cooperation and Development) (Immigration and Ethnocultural Diversity in Canada, 2011). Canada's official statistics website presents «Immigration and Diversity: Population Forecasts for Canada and its Regions, 2011-2036» by Jean-Dominique Morency, Eric Malenfant and Samuel Maclsaak (Immigration and Diversity: Population Projections for Canada and its Regions, 2011 to 2036, 2017). The main purpose of these forecasts is to assess the sensitivity of ethnocultural diversity trends over the next 25 years to some key aspects of immigration, such as the number of new immigrants, their geographical distribution and their origin. In addition, the projections emphasize how these key aspects of immigration may affect the future ethnocultural diversity of different regions of Canada.

Thus, according to the forecasts for the period from 2011 to 2036, immigrants will represent about $30 \%$ of Canada's population. The population for which English and French are not native languages will increase from $20 \%$ to $30 \%$. South Asia is still projected to be a major minority group in 2036, followed by the Chinese. However, the fastest growing groups will be Arab, Philippine and West Asian groups. They make up a larger share of the immigrant population than the general population. As for the religion, a share of people who report a lack 
of religious affiliation in the total population will continue to increase and may range from $28.2 \%$ to $34.6 \%$ in 2036 (compared to $24.0 \%$ in 2011). The same indicators are typical for representatives of the Catholic religion (from 29.2\% to 32.8\% in 2036 compared to 2011 (38.8\%)). In 2036, Catholicism will remain the religion with the largest number of followers. The number of people associated with non-Christian religions could double by 2036 from $13 \%$ to $16 \%$ of Canada's population, comparing to $9 \%$ in 2011. The number of followers of the Muslim, Hindu and Sikh religions, which predominate among immigrants, will grow rapidly, despite the demographically modest share of the entire Canadian population.

Canadian multiculturalism has been successful owing to the government support for the education system that takes into account the cultural multiethnicity of population: more than 70 ethnic groups speak 60 languages, and in many schools students represent more than 20 separate ethnocultural groups (Слоньовська, 2011. с 10).

Today, Canada's multicultural education encompasses all levels, forms and stages of teaching and education and involves creating a favorable pedagogical and psychological climate, mental and moral education of multicultural personality, development of critical thinking, encouragement of actions and decisions in the spirit of humanism and intercultural dialogue, active civil action, etc.

The key principles that ensure the effectiveness of multicultural education in Canada are: the principle of anti-racist education, which rejects racism in all its forms and emphasizes the need to equip students with the ability to actively resist discrimination in a particular life situation nonviolently, in order to prevent its recurrence; the principle of liberating education, the implementation of which requires the formation of students' skills to critically comprehend the information obtained, contributing to the process of birth of new cultural knowledge; the principle of teaching and education based on the experience and interests of students, rather than on the directives of the dominant culture (Бахов, 2017).

\section{MODEL CITIZENS' INTEGRATION THROUGH THE MULTICULTU- RAL EDUCATION IN THE UNITED KINGDOM OF GREAT BRITAIN AND NORTHERN IRELAND}

The multicultural model of society's existence and development, which first appeared in Canada and the United States, became widespread in Europe in the 1980's. An important indicator of the success of multiculturalism policy is the attention of public authorities and the 
community to multicultural education. The development of multicultural education has been closely linked to social, economic and political factors in the world labor market, as well as to the migration flow to Europe, mainly from the Third World countries.

Anna Veretevska writes that «... in Europe, the appeal to the rhetoric of multiculturalism is related, first of all, to the formation of state welfare in the postwar period, which coincided with the final collapse of the colonial system. Going through the process of recovery after the Second World War, Europe has become attractive to immigrants, including members of other (often distant) civilizations» (Веретевская, 2012 b, с. 112).

Indeed, the transition from an assimilation model of minority integration to a multicultural one is due to migration processes. Immigrants who settled in Europe did not assimilate, but, uniting in ethnic communities, actively defended their rights, including the preservation of culture, traditions and customs. Thus, for several decades, the ideas of multiculturalism spread to all European countries.

Great Britain can be described as a multinational country with a long history of creating a system of multicultural education. The development of multicultural education in the UK is closely linked to emigration and immigration. These processes have always been an integral part of the British history.

Unlike Canada, Great Britain did not declare multiculturalism as a state policy toward ethnic minorities, but was one of the first European countries to put multiculturalism into practice.

Today in the United Kingdom, the multicultural education system is based primarily on sound regulation, as well as on the results of numerous government-initiated education studies that have formed the basis for important decisions.

A characteristic feature of the modern system of higher education in the UK is the interdisciplinary approach that underlies the construction of curricula (Бріт аnd Шульга, 2015, c. 75-94). After analyzing the strategy of interdisciplinarity in the programs of British universities, scientists Nadiya Britt and Nataliya Shulga came to the conclusion that this approach is implemented by: combining material from religious, sociological and political disciplines; development of interdisciplinary curricula (language, ethnic and religious), which combine several subjects into one project; use of various modern forms and methods of educational activity (work in laboratory, studio, work with electronic resources of a local network of universities, execution of projects, drawing up of a portfolio, etc.) (Бріт and Шульга, 2015, с. 94). 


\section{THE CITIZENS' INTEGRATION MODEL BY MEANS OF MULTICUL- TURAL EDUCATION IN THE FEDERAL REPUBLIC OF GERMANY}

The development of multicultural education in the Federal Republic of Germany, as well as in the United Kingdom of Great Britain and Northern Ireland, has been influenced by immigration. However, immigration processes in Germany have their own characteristics.

The development of multicultural education in Germany must be analyzed in historical and pedagogical perspective. The preconditions for the emergence of multicultural education in Germany were formed during its historical development and are associated with the presence of internal linguistic and ethnic minorities, the presence of foreigners in German states, migration processes, and the late formation of the nation state in Germany.

Irek Suleymanov identified the following prerequisites for the formation of multicultural education in Germany: socio-economic (due to the migration, labor invitations, changing borders in the process of historical development of Germany, colonial possessions); socio-cultural (determined by the national, ethnic, linguistic and religious heterogeneity of Germany); political and legal (related to the experience of legislating the rights of national, ethnic and linguistic minorities and making the appropriate policy decisions in the field of education); pedagogical (related to experience in the field of pedagogical theory and practice regarding representatives of national, ethnic and linguistic minorities) (Сулейманов, 2010).

We emphasize that the educational policy during this period was aimed primarily at eliminating the cultural, linguistic, ethnic, religious and national heterogeneity of society. However, some experience in supporting ethnic and religious minorities in education has been gained as well. In particular, Irek Suleymanov connects the pedagogical preconditions for the formation of multicultural education in Germany with the experience in the field of pedagogical theory and practice regarding representatives of national, ethnic and linguistic minorities (Сулейманов, 2010): ideas of German teachers about the need to teach in the native language (for example, Holstein teacher Wolfgang Ratke (Ratichius); pedagogical discussions on the problems of «linguistic dichotomy» (since the early XIX ${ }^{\text {th }}$ century); teachers' ideas concerning the liberal attitudes and support for linguistic minorities (Friedrich Wilhelm Schubert, Karl Sigmund von Altenstein etc.); ideas of German comparative pedagogy, within which the ideas of European education (Friedrich Wilhelm von Thiersch), education in the spirit of peace and mutual understanding of peoples (experience in organizing school correspondence, international meetings, exchanges, etc.), the formation of a public German school focused on all subjects; availability of schools with teaching in minority languages (reading, writing, God's 
law), bilingual (foreign) schools; accumulation of experience in teaching German as a native language; experience in organizing schools on a confessional basis (Kingdom of Württemberg); the experience of democratization of the school education system in Germany by the occupying forces (introduction of joint training, the first attempts to implement the ideas of international education in the eastern zone of occupation); experience in organizing classes for children of foreign workers (late XIX ${ }^{\text {th }}$ century); experience in organizing schools for foreigners (French gymnasium in Berlin (XVIII ${ }^{\text {th }}$ century), or Russian schools in the 1920's; discussion on compulsory school attendance by children of foreign nationality (XIX ${ }^{\text {th }}$ century); experience of conceptualization of the topic «Germans abroad» and «Germans of border regions» on the basis of the interdisciplinary principle; experience in preserving the German language in minorities living outside Germany; experience of colonial pedagogy.

The current stage of development of multicultural education in Germany is aimed the development of European self-awareness, the formation of a multi-perspective worldview, the development of an expanded identity and the formation of the «universal humanity» in students (Сулейманов, 2010). However, due to the current policy of the German government and uncontrolled migration, which may threaten the dissolution of the German ethnic group and culture, the Islamization of Germany with further radicalization of the Germans in an attempt to preserve their identity (Трохименко, 2016, с. 72), we can say that any practice of multicultural education implementation cannot be sustainable and requires constant improvement, in accordance with the political, economic and cultural situation in society.

\section{MODEL OF CITIZENS' INTEGRATION BY MEANS OF MULTICUL- TURAL EDUCATION IN THE FRENCH REPUBLIC}

The modern education system in the French Republic is considered to be one of the most advanced in the world. The formation and development of multicultural education in France, as in other European countries, is associated with the mass immigration. After the French Revolution, Republican France became a haven for many immigrants, making it a multinational country. According to historian Fernand Braudel, «the population of France is the canvas woven from different ethnic groups, people from different regions, gathered together, joined by foreigners from European and other, more distant countries, owing to various immigrants that have been going on for more than a century» (Бродель, 1995). The socio-economic situation of the country, which was formed, partly, due to mass migration flows, contributed to the need to address the problems of multicultural education at the state level and directly related 
to its emergence. Vira Lonshakova (Лоншакова, 2011, с. 66) points out the following stages of the multicultural education development:

$\mathrm{I}^{\text {st }}$ stage - the stage of multicultural education formation (50's - 60's of the $\mathrm{XX}^{\text {th }}$ century). It was characterized by a conservative approach, which provided that the «common» culture of the state should be based on the norms of dominant Western European culture and serve as a basis for the content of education, so the culture of ethnic minorities was considered as a complement to it.

II ${ }^{\text {nd }}$ stage - the development and institutionalization of multicultural education (1970's - the second half of the 1980's of the XX ${ }^{\text {th }}$ century). Owing to the reforms of the 1970's, the French education system underwent major changes toward democratization. Vira Lonshakova defines the leading tasks of multicultural education of the $\mathrm{II}^{\text {nd }}$ stage as: elaboration of national self-consciousness, further compensation for unequal access conditions to the prestigious education of representatives of national, cultural and religious minorities. The main task of multicultural education was to study the basics of native culture and culture of France. According to the task, the curricula were to include information about the others, their values, beliefs and patterns of behavior.

The author states the fact that at this stage the model of multicultural education was largely implemented. At the same time, inadequate attention to the problems of educating individuals, who are ready for intercultural dialogue at the state level, has further led to the desire of immigrants, especially those who practice Islam, to establish their cultural or religious priorities.

III ${ }^{\text {rd }}$ stage - a period of crisis in multicultural education (mid 80's - 90's of the XX ${ }^{\text {th }}$ century), that was caused by a return to the assimilation policy. During this period, unresolved contradictions emerged in resolving the problem of constructing educational content between the state's official ideology of educating immigrants only as French citizens and the values of the religious culture of the African immigrants. However, the field of higher education in France in the second half of the twentieth century was characterized by a long way towards the ideology of multiculturalism, during which significant progress was made in shaping the content and strategies of multicultural education: educating elites ready for intercultural dialogue; creating conditions for the adaptation of foreign students to higher education in France; cultivation of world, state and national cultures in the processes of education and training; internationalization. In general, the created structure of higher education was aimed at the development in accordance with the principles of the Bologna Declaration (two-level 
system of higher education, ensuring the quality of education, expanding the mobility of students and teachers, etc.).

It should be noted that the difficult situation of the late $\mathrm{XX}^{\text {th }}$ - early $\mathrm{XXI}^{\text {st }}$ century in the formation of multicultural education in France has not erased the humanistic component of its vast experience and has not stopped the search of innovative teachers for the further development of multicultural education in terms of the Bologna Process trend. Moreover, the analysis of the development of education in France confirmed the legitimacy of using the multicultural education model as a pluralistic approach to the content compilation of education.

It should also be outlined that the reforms in education in France existed notably earlier than the period chosen for study by Vira Lonshakova. The process of the French education system reforming was started during the 1881 - 1882 academic year owing to the Minister of National Education, Jules Ferry. Important, from the point of view of researching the problem of multicultural education is that this reform was based on the three-key principles: it was mandatory for all children aged from 6 to 16, regardless of gender and class, free and secular. Jules Ferry's reform is the basis for the modern French education system, because in the course of the reform was created the administrative and pedagogical structure, which remains almost unchanged till today (Гордиенко, 2013, с. 10).

At present the French government is showing increasing interest to the issue of an international exchange and attracting of the foreign students to higher education establishments of France.

Thus, the republican model of migrants' integration proved its viability in France: first-wave immigrants (Italians, Poles, Russians, Belgians, Spaniards, etc.) were assimilated, and new-wave immigrants (Portuguese, Maghreb natives) are undergoing the process of social and cultural political integration. However, the French model has certain shortcomings. The main problem of immigrants is not as much ethnic or racial differences as the socio-economic position.

\section{LEGISLATIVE SUPPORT OF MULTICULTURAL EDUCATION IN UKRAINE}

Multicultural education in Ukraine became especially relevant during its formation as an independent state focused on the European educational space, as was evidenced by the approval of relevant legislation at the international level. 
State legislation and practice of regulating the ethno-national processes or issues in all spheres of activity were formed by our state in accordance with international norms and recommendations, set forth in the Universal Declaration of Human Rights (Загальна декларація прав людини (рос/укр). ООН, 1948), Framework Convention for the Protection of National Minorities, (Рамкова конвенція про захист національних меншин, 1995), European Charter for Regional or Minority Languages (Європейська хартія регіональних мов або мов меншин, 1992), The Hague Recommendations of the OSCE High Commissioner Regarding the Education Rights of National Minorities and other documents (Гаазькі рекомендації щодо прав національних меншин на освіту, 1996).

While analyzing the legal framework of our state, designed to support and develop intercultural interaction of Ukrainian citizens, we have focused on two aspects of this issue: the reflection in the legal framework of the rights of national minorities and the reflection of ideas of multicultural education. Ukraine has adopted a number of laws, resolutions and edicts in order to regulate the activities of legislative and executive bodies on the regulation of Ukrainian citizens' public life, observance of their democratic rights and freedoms. Regarding the second aspect, one should note that the ideas of multicultural education are reflected in such documents, legislation, laws, regulations and edicts as: the State National Program «Education» («Ukraine of the XXIts century») (Постанова Кабінету Міністрів України № 896, 1993); the National Doctrine of Education Development (Указ президента України № 347, 2002); the National Strategy for the Development of Education in Ukraine until 2021 (Указ президента України № 344, 2013); the Concept of National Education of Student Youth (Рішення Колегії МОН України № 7/2-4, 2009); the Letter of the Ministry of Education and Science, Youth and Sports of Ukraine «On the education of modern citizen in a multicultural environment by means of extracurricular activities» (Лист Міністерства освіти і науки, молоді та спорту України № 1/9-530, 2012) and other documents.

Of course, the ideas of multicultural education are not limited to the above mentioned documents. There are many other documents that in one way or another reflect the issue of our research. These are the Laws «On Freedom of Conscience and Religious Organizations», «On Child Protection», «On Prevention of Domestic Violence», «On Associations of Citizens» and other valid documents, as well as international legal acts ratified by the Verkhovna Rada of Ukraine (Supreme Council of Ukraine). 


\section{CONCLUSIONS}

Underway the study, the fact of the need for the multicultural education and its links with the social, economic and political factors in the global labor market, as well as with the migratory flow that requires the integration of immigrants into society, was found out. However, each country's multicultural education has its own peculiarities.

The United States and Canada have approved its status as an educational policy of the country at the legislative level. Selection and structuring of the content of schedule at different levels of education are based on the ideas of equality, respect and tolerance for other cultures.

The development of multicultural education in the United States and Canada has its own characteristics. In the United States, it was initiated by immigrants as a result of their desire to adapt, under the influence of civil rights movements, against racial discrimination in education. In Canada, the formation of multicultural education took place by finding a compromise between French-speaking and English-speaking communities without giving cultural and educational preference to either of them.

In Western Europe, multicultural education aims at the ensuring of the equal access to higher education for all segments of the population, as well as at the removing of obstacles to the socialization of cultural groups. It also supports the reproduction and development of different cultures and promotes cultural pluralism as a key characteristic of civil society.

Multicultural education in the United States, Canada, and Western Europe has been shown to play an important role in the integration of the individual into society.

Some of the ideas of multicultural education of different countries can be implemented into the educational process of higher education establishments of Ukraine. These are the following: to use the information about different cultures and social groups in the content of psychological and pedagogical disciplines; the idea of developing in teachers the skills of critical thinking concerning the same object or phenomenon; formation of impartiality in views on ethnic identity; polylingual learning; achieving of the equal opportunities during the learning process for all students.

The analysis of the multicultural education development in different countries revealed common sociocultural preconditions for its emergence: migration processes caused by the socioeconomic and political situation of the country and the impact of globalization on culture, i.e. "cultural globalization". 
The research does not cover all aspects of the problem. We still have to deal with the problem of the mass media influence on the future teacher's personality formation as a person which is supposed to be the culture carrier during the educational process; foreign experience in training teachers for multicultural education; the problem of improving and filling up of the psychological and pedagogical disciplines with the multicultural content; statistics on the state of the multicultural education system in Ukraine and abroad.

The state of multicultural education in Ukraine indicates the formation of a legislative framework aimed at the development of multicultural education. However, its ideas have no practical implementation, and the issue of their implementation remains only at the level of proclaimed declarations.

\section{REFERENCES}

Бахов, І. (2017). Тенденції розвитку полікультурної освіти у професійній підготовці фахівиів Канади і США (друга половина XX - початок XXI cm.). (Дис. докт. пед. наук) Національний педагогічний університет імені М.П. Драгоманова, Київ.

Бріт, Н., Шульга, Н. (2015). Організаційно-педагогічні засади розвитку полікультурної освіти у вищих навчальних закладах Великої Британії: монографія. Умань: ФОП Жовтий.

Бродель, Ф. (1995). Что такое Франция? Книга вторая. Люди и вещи. (Часть1). Москва: Изд-во Сабашниковых.

Веретевская, А. (2012 а). Канадский мультикультурализм: исторический аспект. Вестник Российского государственного гуманитарного университета. Серия «Международные отношения. Регионоведение». 19 (99), 147-159.

Веретевская, А. (2012 b). Перспективы и препятствия для политики мультикультурализма в консолидированных демократиях Западной Европы. (Дис. канд. политических наук). Федеральное государственное бюджетное учреждение высшего профессионального образования «Московский государственный институт международных отношений (университет) Министерства Иностранных дел Российской Федерации». Москва.

Гаазькі рекомендації щодо прав національних меншин на освіту. (1996).

Гордиенко, Н. (2013). Профессионализм и компетентность в системе высшего педагогического образования Франции: учебное пособие для студентов педагогических вузов. Коломна.

Європейська хартія регіональних мов або мов меншин. 994_014. (1992). 
Загальна декларація прав людини (рос/укр). ООН. 995_015. (1948).

Куропятник, А. (2000). Мультикультурализм: идеология и политика социальной стабильности полиэтнических обществ. Журнал социологии и социальной антропологии, III (2), с. 53-66.

Лист Міністерства освіти і науки, молоді та спорту України № 1/9-530. (2012). «Щодо виховання сучасного громадянина в полікультурному середовищі засобами позакласної роботи».

Лоншакова, В. (2011). Развитие мультикультурного образования Франции: вторая половина $X X$ века. (Дис. канд. пед. наук). Забайкальский государственный гуманитарнопедагогический университет имени Н.Г. Чернышевского. Чита.

Постанова Кабінету Міністрів України № 896. Про Державну національну програму «Освіта» («Україна ХХІ століття»). (1993).

Рамкова конвенція про захист національних меншин. 995_055. (1995).

Рішення Колегії МОН України № 7/2-4. (2009). «Про затвердження Концепції національного виховання студентської молоді».

Слоньовська, О. (2011). Полікультурна освіта майбутніх учителів гуманітарних дисциплін y вищих навчальних закладах Канади. (Автореф. дис. канд. пед. наук). Житомирський державний університет імені Івана Франка. Житомир.

Сулейманов, И. (2010). Становление и развитие поликультурного образования в Германии. (Дис. канд. пед. наук). Ульяновский государственный педагогический университет имени И.Н. Ульянова, Ульяновск.

Трохименко, О. (2016). Міграційна криза та проблема поширення правих настроїв у сучасному німецькому суспільстві. Наукові записки Національного університету «Острозька академія». Серія: Культурологія, 17, 72-83.

Указ президента України № 344. (2013). «Про національну стратегію розвитку освіти в Україні на період до 2021 року».

Указ президента України № 347. (2002). «Про Національну доктрину розвитку освіти».

Allport, G. (1954). The Nature of Prejudice. Mazal Holocaust Collection. Cambridge MA: Addison-Wesley.

Banks, J. (1993). Multicultural education: Historical development, dimensions, and practice. Review of Research in Education, American Educational Research Association, 19, 3-49, 19-20.

Banks, J. and Ambrosio, J. (2016). Multicultural Education - History, The dimensions of Multicultural education, Evidence of the Effectiveness of Multicultural education. Education Encyclopedia - StateUniversity.com. Retrieved from: http://education.stateuniversity.com/pages/2252/Multicultural-Education.html. 
Grant, C. (2008). The Evolution of multicultural Education in the United States: A Journey for human Rights and social Justice. Social Foundations of Education: Multicultural Education. Retrieved from: http://libguides.rutgers.edu/c.php?g=336784\&p=2267275 та http://www.iaie.org/download/turin paper_grant.pdf.

Immigration and Diversity: Population Projections for Canada and its Regions, 2011 to 2036. (2017). Retrieved from: http://www.statcan.gc.ca/pub/91-551-x/91-551-x2017001-eng.htm.

Immigration and Ethnocultural Diversity in Canada. (2011). National Household Survey. Retrieved from: http://www12.statcan.gc.ca/nhs-enm/2011/as-sa/99-010-x/99-010-x2011001-eng.pdf

Landes, X. (2013). Le Canada, solution au problème d'identité européen? Slate FR. Retrieved from: http://www.slate.fr/tribune/72049/canada-multiculturalisme-europe.

Wieviorka, M. (1998). Is Multiculturalism the Solution? Ethnic and Racial Studies, 21 (5), 881-910. 